\title{
An arachnoid cyst with intracystic hemorrhage. Rare complications of a common CNS lesion
}

\section{Krwawienie do torbieli pajęczynówki. Rzadkie powikłania częstej zmiany OUN}

\author{
Agata Hałabuda' ${ }^{1}$, Łukasz Klasa², Stanisław Kwiatkowski², Łukasz Wyrobek', Olga Milczarek ${ }^{2}$ \\ ${ }^{1}$ Zakład Radiologii, Uniwersytecki Szpital Dziecięcy w Krakowie \\ ${ }^{2}$ Oddział Neurochirurgii, Uniwersytecki Szpital Dziecięcy w Krakowie
}

\section{ABSTRACT}

The Sylvian arachnoid cyst is a common benign disease, however sometimes leads to subdural or intracystic hemorrhage without major trauma. The reason of easy bleeding of the arachnoid cyst is not fully understood. A decision to employ surgical treatment of arachnoid cysts complicated by coexisting subdural hematoma and/or bleeding to the lumen of the cyst should be reached in close correlation with clinical symptoms. Although surgical therapeutic modality is commonly recognized in such situations, yet due to the risk of postoperative complications, should be reserved for cases with repeated bleedings and intracranial hypertension. A surgical intervention in the case of mild bleeding without coexisting intracranial hypertension should be considered with extreme caution, since instances of spontaneous resolution of bleeding have been known. The presented here cases of arachnoid cysts complicated by bleeding required surgical interventions in view of clinical and radiological symptoms of intracranial hypertension.

Keywords: arachnoid cyst, epilepsy, subdural hematoma

\section{STRESZCZENIE}

Torbiel szczeliny Sylwiusza jest łagodną zmianą, zazwyczaj rozpoznawaną przypadkowo. Bardzo rzadko może dojść do powikłań w postaci krwawienia do jej światła lub przestrzeni podtwardówkowej. Mechanizm tego zjawiska nie jest do końca poznany. Decyzja o leczeniu chirurgicznym torbieli pajęczynówki powikłanej krwiakiem podtwardówkowym lub krwawieniem do jej światła powinna być podejmowana w ścisłej korelacji z objawami klinicznymi. Jakkolwiek chirurgiczna metoda leczenia $w$ takiej sytuacji jest powszechnie uznawana, to jednak ze względu na ryzyko pooperacyjnych powikłań powinna być zarezerwowana dla przypadków powtarzających się krwawień i przebiegających z objawami ciasnoty śródczaszkowej. Interwencja chirurgiczna przy niewielkim krwawieniu, bez objawów ciasnoty śródczaszkowej, powinna być rozważana bardzo ostrożnie, ponieważ znane są przypadki samoistnego ograniczenia krwawienia. Prezentowane w niniejszej pracy przypadki torbieli pajęczynówki powikłanych krwawieniem wymagały interwencji chirurgicznej ze względu na kliniczne i radiologiczne cechy ostrej ciasnoty śródczaszkowej.

Słowa kluczowe: torbiel pajęczynówki, padaczka, krwiak podtwardówkowy

\section{PATHOPHYSIOLOGY}

Arachnoid cysts (ACs) are defined as abnormal fluid accumulation contained between a duplicated arachnoid membrane. Their incidence in children is estimated as $2.6 \%$ [1, $2,3]$ and the number is growing together with an increasing availability and frequency of performing medical imaging for various ailments. With respect to their location, arachnoid cysts are divided as follows:

1. Cysts of the lateral (Sylvian) fissure of the brain the most commonly observed type, accounting for approximately $50-60 \%$ of cases.

2. Cysts of the posterior fossa - second in frequency, accounting for $10-30 \%$ of cases, further subdivided into:

- Cysts of the cerebropontine angle.

- Cerebellar hemisphere cysts.

- Median retrocerebellar cysts that need to be differentiated from:
- Dandy Walker syndrome;

- Dandy Walker variant;

- distended cisterna magna.

3. Cortical cysts.

4. Suprasellar cysts.

Median retrocelebellar cysts are divided based on neuroimaging (CT and MRI), in keeping with the classification developed by Raybaud and Barkovich [4,5].

The majority of ACs (approximately 60-80\%) are detected in patients younger than 16 years of age, most often accidentally, and in longitudinal follow-up, they do not demonstrate any changes in imaging examinations and do not evoke any clinical symptoms. In some instances, the size of a cyst may evolve, i.e. the cyst may increase, decrease, spontaneously rupture or, in very rare cases, resolve itself [6]. 
Rare cases of symptomatic ACs may cause headaches, epilepsy, paresis and symptoms of intracranial hypertension. Complications may develop, manifested as intracystic hemorrhage or bleeding to the subdural space.

The mechanism underlying the latter phenomenon has not been fully elucidated.

Page et al. [7] proposed two theories in an attempt to explain this mechanism.

The first theory assumes damage to the superior cerebral veins (small veins situated between the arachnoid and internal layer of the dura mater) or to vessels located in the cyst wall due to easy transmission of pressure by the cyst.

The other theory points to the fact that ACs are less susceptible than normal brain to amortize the force of injury. The swinging motion that results from even a mild intracystic injury is shifted to the external wall of the cyst, causing the tearing of small vessels.

An attempt at explaining the phenomenon was also undertaken by Chang-Hyun Lee et al. [1], who published conclusions drawn from their experiments in Child. Nerv. Syst. in 2014.

In case of an injury, a greater force is focused on the external AC wall than on the remaining normal brain regions, most likely due to different properties of the cerebrospinal fluid and the brain. As a result, an arachnoid cyst is distorted more easily than the brain, evoking excessive motion between the dura mater and the external wall of the cyst. This triggers a secondary effect of turbulent dispersion of pressure within the cyst, contrary to the remaining regions of the normal brain, where pressure disperses in a linear manner.

The vessels within the wall or the external wall of the cyst are torn and the subdural space is distended as a consequence of accumulation of the cerebrospinal fluid mixed with a small volume of non-clotting blood from the damaged small vessels.

The superior cerebral veins between the dura mater and the arachnoid are stretched and secondarily torn.

In turn, Cress et al. [2] in their paper on risk factors of damage or intracystic hemorrhage in ACs, besides an injury itself, took into account also the cyst size and the effect of external pressure (altitude above sea level of the place of residence).

The authors demonstrated that the probability of intracystic and/or subdural space hemorrhage increased with the cyst size. An arachnoid cysts with the highest diameter equal to or larger than $5 \mathrm{~cm}$ were 16.5 times more likely to rupture as compared to cysts below $5 \mathrm{~cm}$.

On the other hand, in their opinion, the third investigated parameter, i.e. external pressure, did not exert any effect on a possible increase of the risk of hemorrhage.

\section{TREATMENT}

There is no consensus as to the management of cases of concomitant AC and chronic subdural hematoma (CSDH).

Reports published to date indicate that such bleeding is rare and has a rather mild course; such lesions also often resolve spontaneously. This is why a decision about surgical management should be reserved to cases of recurrent hemorrhages and patients with symptoms of acute intracranial hypertension, since the risk of postoperative complications is high.

Postoperative complications include:

- intracranial emphysema;

- chronic or subacute hematomas or hematoma hygromas;

- $\quad$ subdural empyemas;

- meningitis;

- liquorrhea;

- $\quad$ cranial nerve palsy;

- $\quad$ pseudo encephalocele;

- hydrocephalus;

- epilepsy;

- paresis.

Another argument against an unduly early surgical intervention is the fact that hemorrhage generally originates from very small vessels, often not visible in the surgical field rendering impossible their direct closure. It should be borne in mind that the very small caliber of the bleeding vessels is the fundamental reason of the chronic character of hemorrhage processes.

Bleeding originating from such small vessels is a continuous, low seepage. Moreover, vessels that have been once damaged are more susceptible to subsequent small injuries and further episodes of bleeding. The slow rate of seepage causes the extravasated blood and the coagulation factors to become considerably diluted in the cerebrospinal fluid, preventing the normal clotting with formation of a typical hematoma and its further evolution.

Should a decision to employ surgical treatment be reached, it is postulated to perform a small craniotomy or to cut only a trephine hole followed by CSDH resection with a simultaneous (microscopic or endoscopic) fenestration of the arachnoid cysts to the cerebral cisterns in order to decrease its volume and, by the same token, the risk of further episodes of damage and/or bleeding. The opening created in the course of the fenestration should be located in the lowest $\mathrm{AC}$ point $[8,9]$.

According to the most current reports, treatment consisting in extensive craniotomy and resection of the cyst walls is not recommended. Such a procedure is associated with a higher rate of complications, both early and late, as compared to limited craniotomy, including CSN damage and neurological symptoms.

Implantation of an external drainage system is also not indicated in view of the possible recurrence of hemorrhaging and the risk of neuroinfections.

In case of a surgical failure or ineffectiveness of the above methods and persisting $\mathrm{CSDH}$ and intracranial hypertension, the implantation of a cysto-peritoneal draining system with a low-medium or low pressure valve or a programmable valve opening pressure should be considered.

If shunt management is employed, such complications may additionally develop as shunt impatency, drain pullage and disattachment and ascites (the complication rate is approximately $50 \%$ ) [8]. 
PRESENTATION OF TWO CASES OF ARACHNOID CYSTS PRECEDED BY A MILD TRAUMA AND ACCOMPANIED BY SYMPTOMS OF ACUTE INTRACRANIAL HYPERTENSION.

\section{Case 1}

A 15-year-old previously healthy boy reported to University Children's Hospital of Krakow with severe headache developed on the day of admission.

During medical history taking, he reported a mild head trauma sustained while skiing 2-3 weeks previously. He had not visited a doctor immediately after the trauma for lack of alarming symptoms.

On the day of admission, the patient was in good general condition, conscious, maintaining logical verbal contact and spatial and temporal orientation; he manifested psychomotor agitation. Neurological examination revealed meningeal signs. No signs of focal CNS damage were noted.

A CT scan of the head demonstrated a large arachnoid cyst of the lateral (Sylvian) fissure of the brain (Galassi type II) with a mass effect manifested as a mild left displacement of the midline of the brain and compression of the right lateral ventricle.

Based on the CT scan and clinical presentation, the boy was qualified for immediate surgical treatment. The cyst was fenestrated and drained into the basal cisterns resulting in a decrease of the cyst size (a lower risk of future bleeding); a hygroma with hematoma was also excised. Following surgery, the above described signs resolved. In view of the periodically reported disturbances of visual acuity, an ophthalmological consult was recommended - no papilloedema was observed, bilaterally, the retinas showed no pathological lesions. The patient was discharged without meningeal signs and without any signs of focal CNS damage.

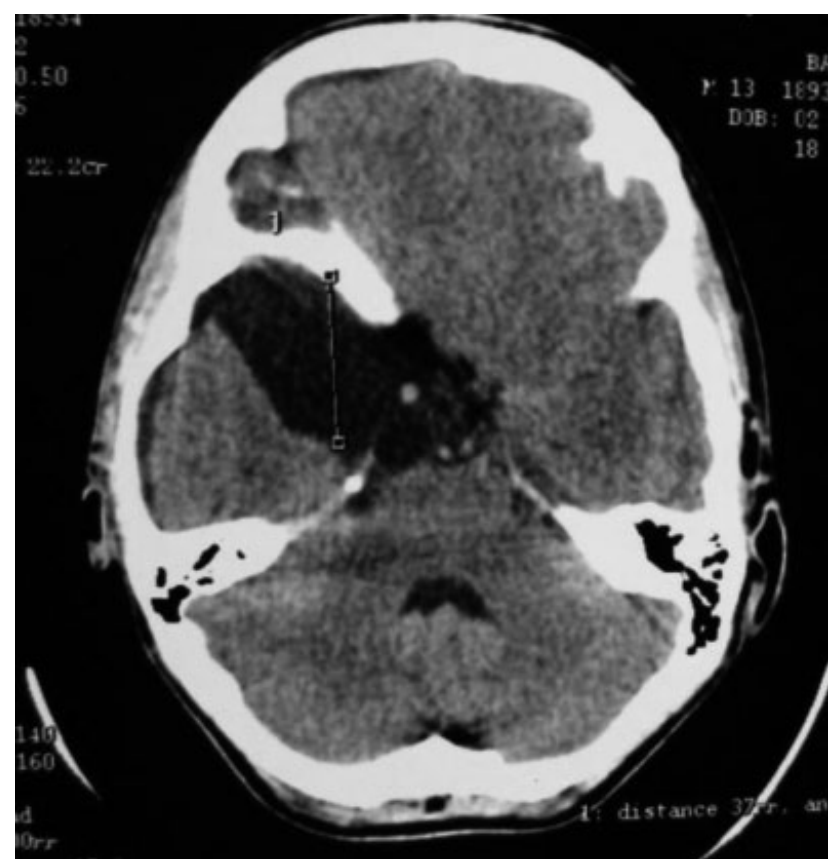

Fig. 1. Axial head NECT. An arachnoid cyst of the middle cranial fossa on the right side (Galassi type II), a small subdural hygroma with hematoma in the right temporal region

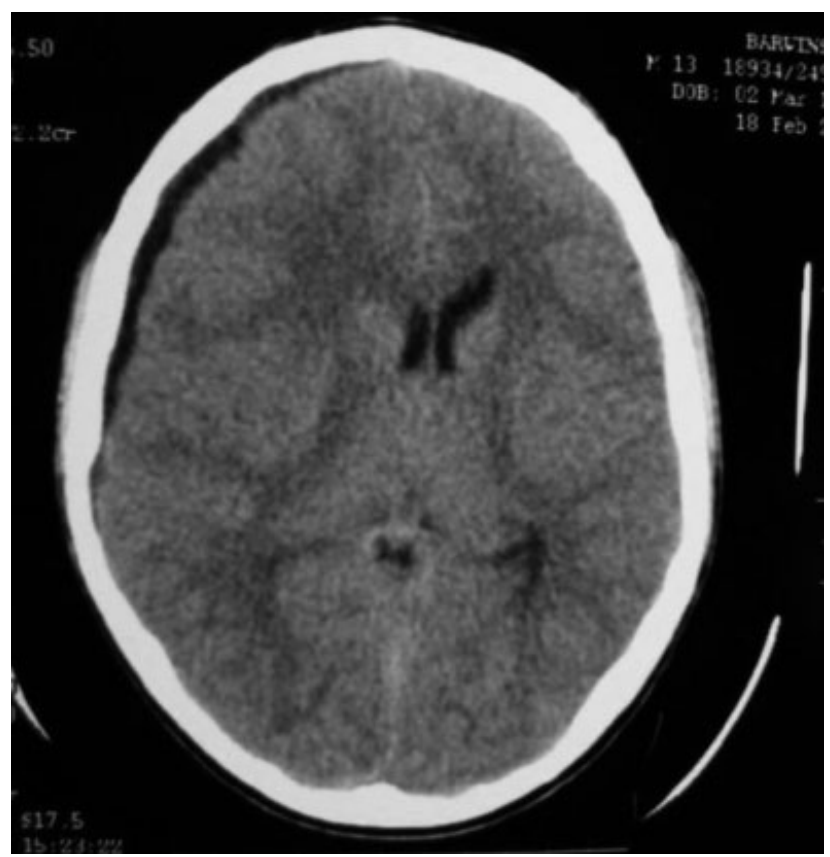

Fig. 2. Axial head NECT. A subdural hygroma with hematoma on the right side, a mass effect manifested as a mild left displacement of the midline of the brain and compression of the right lateral ventricle

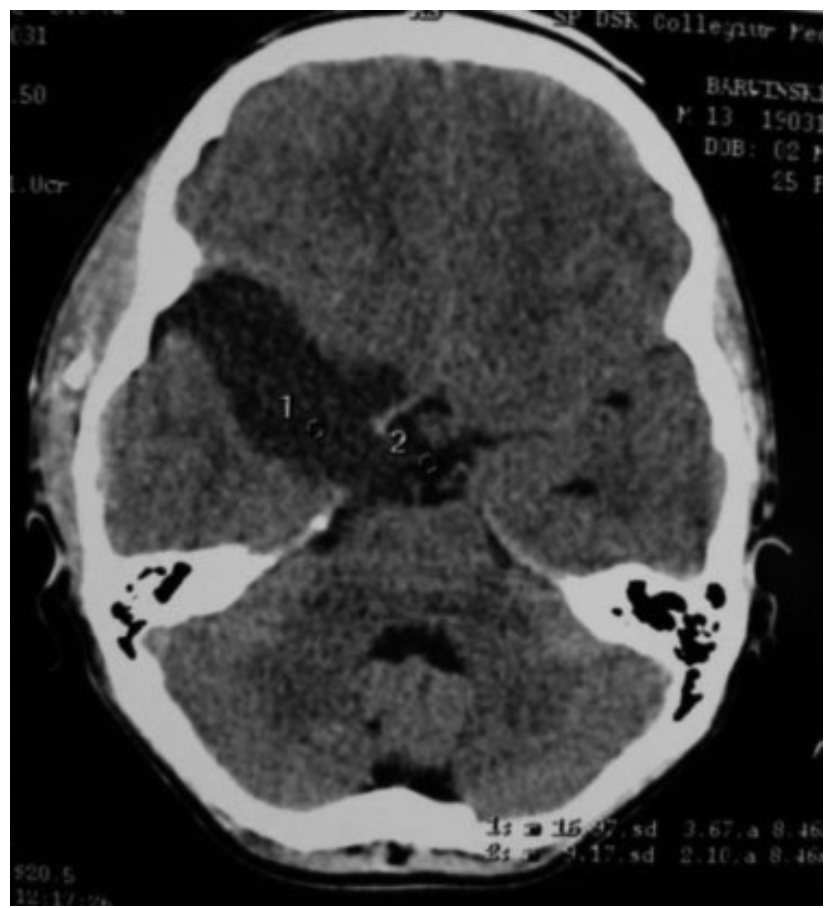

Fig. 3. Axial head NECT. Status after a neurosurgical procedure. The cyst size is decreased, no subdural hygroma with hematoma is seen in the right temporal region

In the course of the 10-year follow-up, no alarming headache episodes were noted nor were deficit-associated symptoms observed in neurological examinations. 


\section{CASE 2}

A 17-year-old previously healthy boy who had sustained a head trauma while playing ice hockey two months prior to admission. He was diagnosed abroad immediately after the trauma (no medical records available; no neurological abnormalities in medical history taking). He came to University Children's Hospital of Krakow because of headaches persisting for approximately two months with subsequent visual disturbances manifested as double vision and impaired visual acuity.

Neurological examination revealed grade III (Lovett) left-sided hemiparesis. Ophthalmologically, the patient presented no abnormalities in eye fundus examination.

The patient was referred for a CT scan of the head, which demonstrated a cyst of the lateral (Sylvian) fissure of the brain on the right side with bilateral hygromas and hematomas in the frontal lobes, mild cerebral edema and a mass effect manifested as a discrete displacement of the longitudinal fissure of the brain to the left.

Based on the CT scan and in view of his clinical presentation (symptoms of acute intracranial hypertension), the patient was qualified for surgical treatment. The cyst was fenestrated and drained to the basal cisterns. The patient was discharged on the 5th post-operative day in good general condition without meningeal signs and signs of focal CNS lesions.

The boy returned to unlimited physical activity (he was a professional ice hockey player). In the 4-year follow-up, no alarming neurological signs were observed.

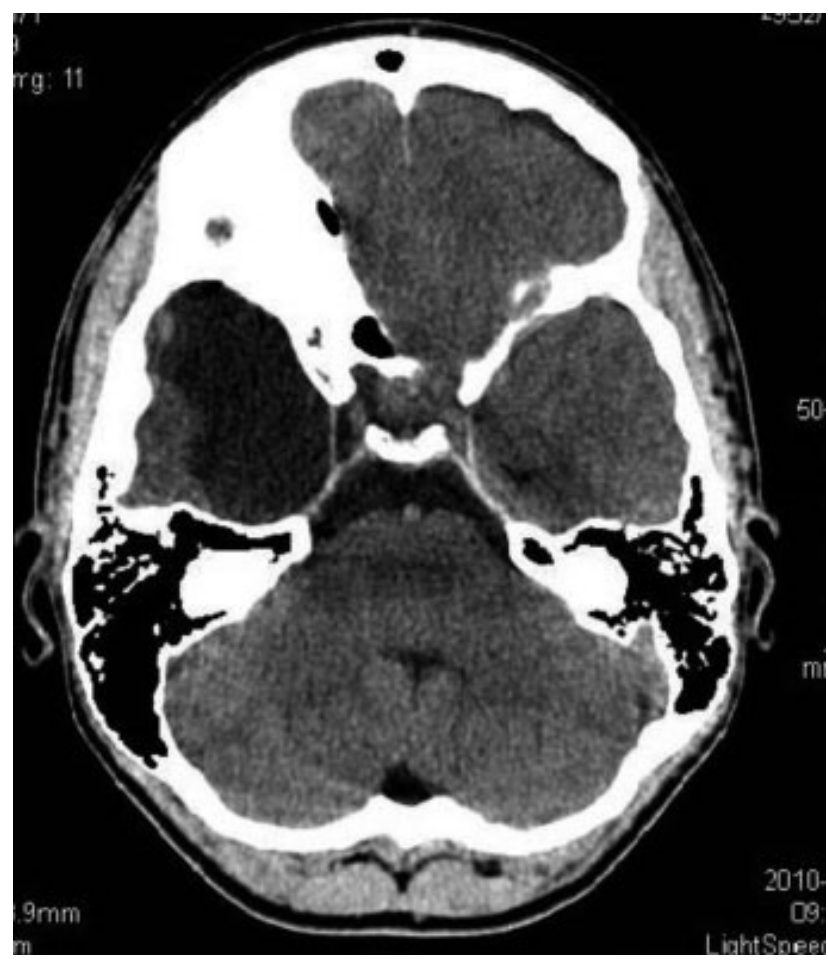

Fig. 4. Axial head NECT. An arachnoid cyst of the transverse fissure of the brain on the right, Galassi type II, with hypotrophy of the temporal lobe

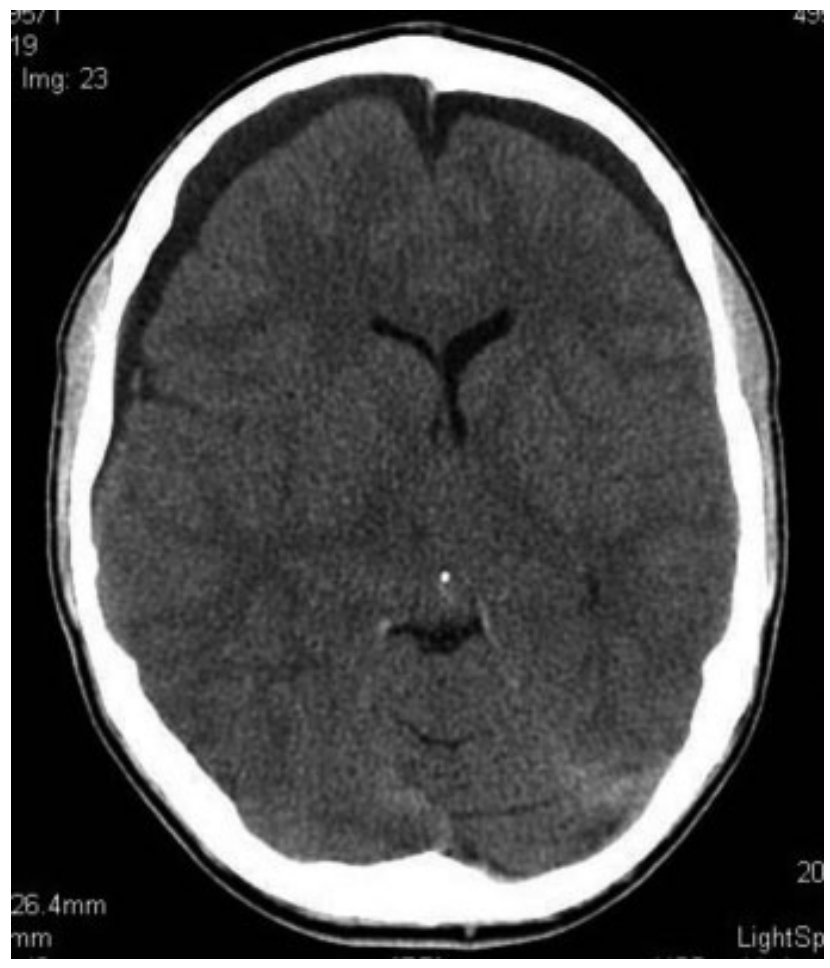

Fig. 5. Axial head NECT. Bilateral subdural hygromas and hematomas, a mass effect manifested as a discrete displacement of the longitudinal fissure of the brain to the left and compression of the right lateral ventricle

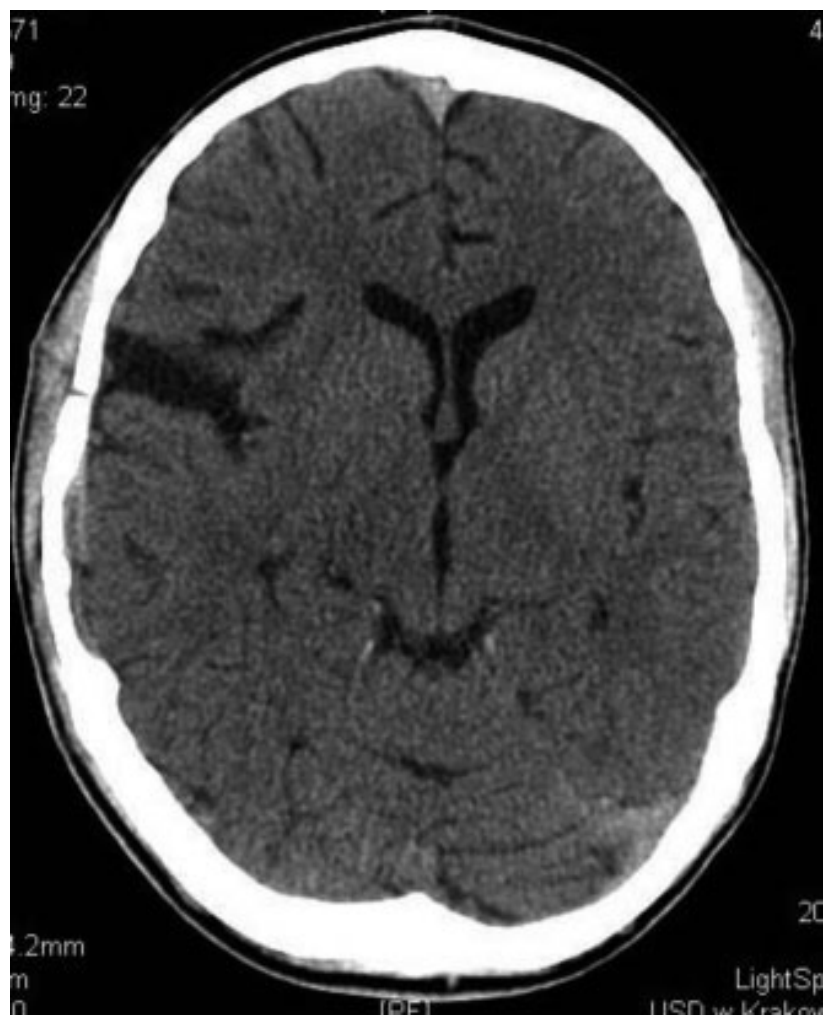

Fig. 6. Axial head NECT. Postoperative status - resection of paracerebral hygromas with hematomas, no displacement of the midline of the brain, decreased compression of the right lateral ventricle, the sulci and fissures are better visualized, what is the result of resolved symptoms of intracranial hypertension 


\section{CONCLUSIONS}

Our experience to date confirms the validity of the management method of arachnoid cysts described in the reports authored by Kwak Y. S. et al. [11] and Lee C-H et al. [1] in case of complications consisting in paracerebral hygromas with hematomas. Adequately to the clinical presentation, surgery employing limited craniotomy is a modality that offers an excellent chance for decreasing intracranial hypertension and the risk of recurrent bleeding from chronic hygromas with hematomas.

\section{DISCUSSION}

The two presented cases of intra-arachnoid cyst hemorrhage involve the lateral fissure of the brain and thus represent the most common location. Hemorrhaging into other CA types is very rare and indications for their surgical treatment consist in diverse symptoms (hydrocephalus, endocrine disorders, mass effect).

Since arachnoid cysts of the lateral fissure are frequently detected, increaslingly more and more often by accident - the patients ask whether there are any indications for surgery and whether there is a risk of bleeding into such a lesion. In the majority of cases, such questions are asked by parents and reflect their concern over their children with respect to the danger of hemorrhage, the risk of engaging in sports or even very mild physical activity.

Undoubtedly, Galassi type I cysts do not require surgical treatment. In type II, if the patient presents with headaches corresponding to the cyst location, which are not typical vasomotor or migraine headaches, and X-ray demonstrates signs of intracranial hypertension or the cyst being "filled up", operative treatment may be executed. The selection of a method is limited to fenestration of the lowest part of the cyst and creating communication with the basal cisterns or to implantation of a cysto-peritoneal shunt. Therapeutic outcomes in both methods are identical; nevertheless, immediate postoperative complications are more severe in the fenestration group, while late complica- tions manifested as typically shunt-associated events are seen in the other group. It should be also borne in mind that the area of communication between the cyst and the cisterns may close, especially when there was intraoperative bleeding from the cyst site; such patients often require subsequent implantation of a cysto-peritoneal shunt. Patients with detected type III cysts rquire surgical treatment as described above.

An acute or chronic subdural hematoma, developed in a patient with an arachnoid cyst, is most commonly manifested by intracranial hypertension - either acute or progressive. Surgical treatment should be employed. Even a small in size subdural hematoma resulting from bleeding into an arachnoid cyst, and the presence of blood in the lumen of the cyst will subsequently lead to the disturbances in cerebrospinal fluid reabsorption, the cyst increasing in size or even to the development of posthemorrhagic hydrocephalus. An exception may be small planar chronic hematomas and a small arachnoid cyst. Rupture of the cyst wall in the course of bleeding and venous blood mixing with cerebrospinal fluid results in a non-clottable mixture, which can be completely resorbed. Self-healing occurs, i.e. a spontaneous fenestration. In such a situation, surgical treatment does not lead to good results, since finding a small vein is almost impossible while performing a craniotomy, and exposing the dura mater causes intensified bleeding and is associated with the risk of postoperative complications. A question emerges whether there are any radiological prognostic factors indicative of bleeding into an arachnoid cyst. There are no such factors and for the question whether there are any factors indicating preventive surgical treatment, there is only one answer - apart from the Galassi classification- there are none. The proposed theory that such factors are represented by the presence of both venous and arterial vessels in the cyst wall or even in its lumen in X-ray imaging does not speak about factors that are prognostic, but rather indicative of a higher risk of intraoperative postoperative complications.

\section{LITERATURE}

[1] Lee C.H., Han I.S., Lee J.Y., et al.: Analysis of bleeding mechanism in patient with the sylvian arachnoid cys using a finite element model. Childs Nervous System 2014; 30: 1029-1036.

[2] Cress M., Kestle J.R.W., Holubkov R., et al.: Risk factors for Pediatric Arachnois Cyst Rupture/Hemorrhage A Case Control Study Neurosurgery 2013; 72: 716-722.

[3] Ali Z.S., Lang S.S., Baker D., et al.: Pediatric intracranial arachnoid cyst: comparative effectiveness of surgical treatment options. Childs Nervous System 2014; 30: 461-469.

[4] Winczewska-Wiktor A., Steinborn B., Młodzikowska-Albrecht J., et al.: Analiza obrazu klinicznego pacjentów w wieku rozwojowym z rozpoznanymi torbielami wewnątrzczaszkowymi/The analysis of clinical symptoms of patients in developmental age with intracranial cysts. Neurologia Dziecięca/Child Neurology 2006; 29: 35-44.

[5] Adeeb N., Deep., Watanabe K., et al.: The intracranial arachnoid mater. A comprehensive review of its history, anatomy, imaging, and pathology. Childs Nerv Syst 2013; 29: 17-33.

[6] Moon K.S., Lee J.K., Kim J.H., et al.: Spontaneous disappearance of a suprasellar arachnoid cyst: case report and review of the literature. Child Nerv Syst. 2007; 23: 99-104.

[7] Page A., Paxtan R.M., Mohan D.: A reappraisal of the relationship between arachnoid cyst of the middle fossa and chronic subdural hematoma. Journal Neurolog Neurosurg Psychiatry 1987; 50: 1001-1007.

[8] Kwiatkowski S.: Powikłania w leczeniu zastawkowym. [w:] Zakrzewski K. (red.): Wodogłowie i inne zaburzenia krążenia płynu mózgowordzeniowego u dzieci. Wydawnictwo Czelej, Lublin 2007, 67-79.

[9] Nasser M.F., El-Ghandour M.D.: Endoscopic treatment of middle cranial fossa arachnoid cyst in children. J Neorosurg Pediatrics 2012; 9: 231238.

[10] Starzyk J., Kwiatkowski S., Urbanowicz W., et al.: Suprasellar Arachnoidal Cyst as a Cause of Precocious Puberty - Report of Three Patients and Literature Overview. Journal of Pediatric Endocrinology \& Metabolism 2003; 16: 447-455. 
[11] Kwak Y.S., Hwang S.K., Park S.H., et al.: Chronic subdural hematoma associated with the middle fossa arachnoid cyst: pathogenesis and review of its managment. Childs Nervous System 2013; 29: 77-82.

[12] Mattei T.A.: Pediatric Arachnoid Cyst and Subdural Hygromas in Early Infancy: Challenging the Direction of the Causality Paradigm. Neurosurgery 2014

[13] Wester K., Helland C.: How often do chronic extra-cerebral haematomas occur in patient with intracranial arachnoid cyst? J Neurol Neurosurg Psychiatry 2008; 79: 72-75.

[14] Poirrier A., L., Ngosso-Tetanye I., Mouchamps M., et al.: Spontaneous arachnoid cyst rupturę in a previously asymptomatic child: a case report. European Journal of Pediatric Neurology 2004; 8:247-251.

[15] Kocaeli H., Korfali E.: Rupture of a small middle cerebral artery aneurysm into middle fossa arachnoid cyst presenting as a chronic subdural hematoma. Acta Neurochir (Wien) 2008; 150: 407-408.

[16] laconetta G., Exposito M., Maiuri F., et al.: Arachnoid cyst with intracystic haemorrhage and subdural haematoma: case report and literature review. Neurol Sci 2006; 26: 451-546.
[17] Puchalska-Niedbał L., Jeżewski D.: Nagłe zaniewidzenie jako następstwo dekompresji po usunięciu torbieli pajęczynówki okolicy skroniowej. Opis przypadku. /Sudden loss of vision as the result of the decompression after the removal of the arachnoid cyst of the temporal region. Case report. Roczniki Pomorskiej Akademii Medycznej w Szczecinie/Annales Academiae Medicae Stetinensis 2007; 53, suppl. 1:80-84.

[18] Nowosławska E.: Torbiele pajęczynówki. [w:] Zakrzewski K. (red.): Wodogłowie i inne zaburzenia krążenia płynu mózgowo-rdzeniowego u dzieci. Wydawnictwo Czelej, Lublin 2007, 143-156.

[19] Donelly L.F., et al.: Schizencephalia. [w:] Diagnostic Imaging Pediatrics. Amirsys Inc 2005, rozdz. 7, 34-37.

[20] Osborn A.G.: Salzman K.L. Barkovich A.J.: Schizencephaly. [w:] Diagnostic Imaging Brain. Amirsys Inc 2010, rozdz. 177-80.

[21] Siegal Marylin J.: Ultrasonografia pediatryczna. MediPage, Warszawa 2012.

\section{Adres do korespondecji:}

Agata Hałabuda, Uniwersytecki Szpital Dziecięcy w Krakowie, Pracownia Radiologii, ul. Wielicka 265, 30-663 Kraków, agatahalabuda@gazeta.pl 